\title{
Od rewaloryzacji idealnego miasta do ochrony historycznego krajobrazu Zamościa
}

\section{Krzysztof K. Pawłowski}

Zamość, który w 2017 roku obchodzi 25-lecie wpisu na listę Dziedzictwa Światowego UNESCO ${ }^{1}$ jest świetnym przykładem ewolucji podejścia do ochrony miejskich zespołów zabytkowych w Polsce. Będzie on niewątpliwie przedmiotem pogłębionych analiz związanych z przypadającym w roku 2018 100-leciem tworzenia zalążków służb konserwatorskich.

Zamość był bowiem jednym z pierwszych zespołów miejskich wpisanych do rejestru zabytków w 1936 roku, które w 1938 roku otrzymało plan zagospodarowania przestrzennego uwzględniający cały kompleks problemów konserwatorskich. Jego autorem był Jan Zachwatowicz przy współpracy Antoniego Wieczorkiewicza.

Opracowanie planu urbanistycznego poprzedzone było wnikliwym studium Stanisława Herbsta i Jana Zachwatowicza - "Twierdza Zamość" wyrosłym na gruncie interdyscyplinarnej współpracy wprowadzanej w życie przez Zakład Architektury Polskiej na Wydziale Architektury Politechniki Warszawskiej.

Jan Zachwatowicz prowadził też w Zamościu prace projektowe i realizacyjne. Według jego projektu urządzono Park Miejski, którego istotnym elementem był zarys jednego z bastionów z ziemnym nadszańcem. Jego dziełem była też rekonstrukcja starej Bramy Lwowskiej. Inicjatywy obejmujące również inne obiekty przerwane zostały przez II wojnę światową i okupację hitlerowską, która dla Zamościa miała tragiczne konsekwencje. Miał się on stać stolicą zgermanizowanego przez Niemców regionu, co spowodowało deportacje i eksterminacje ludności.

Po wojnie pierwsze większe prace podjęto w latach 1956-57. Od 1963 roku prowadzone były kompleksowe prace konserwatorskie w kilku blokach zabudowy wschodniej części miasta. Rychło jednak zostały ocenione krytycznie, między innym za zbyt daleko idące ingerencje w formy budynków i nie poszanowanie dawnych podziałów własnościowych.

Ponieważ w tytule posłużyłem się pojęciem „miasta idealnego" rozpocznę od przypomnienia, że wśród badaczy układu przestrzennego Zamościa pierwszorzędne miejsce zajęła prof. Teresa Zarębska². To ona przedstawiła próbę odtworzenia czterech głównych faz formowania planu opartego na idei włoskich twórców renesansu. Położyła nacisk na problem zespolenia miasta z rezydencją (Ryc. 1). Znane są przyczyny odstępstwa od pełnej regularności zarysu obwarowań wynikających z konieczności dostosowania do warunków terenowych - przede wszystkim układu wodnego ${ }^{3}$ (Ryc. 2).

Prace realizacyjne hamowane były brakiem środków finansowych a również możliwości wykonawczych. Dzięki współdziałaniu władz miejscowych z Ministerstwem Kultury udało się doprowadzić w 1974 roku do uchwały Rady Ministrów ${ }^{4}$ w sprawie odnowy Starego Miasta w Zamościu. Był to moment przełomowy w dziejach miasta i procesie jego rewaloryzacji.

W moim szkicu zamierzam zasygnalizować podstawowe wątki tej problematyki, w której w pewnym zakresie udało mi się uczestniczyć w ostatnim ćwierćwieczu XX-go wieku, gdyż wydaje się, że stanowiły one bazę dla bardzo licznych debat i co istotne również działań realizacyjnych ${ }^{5}$. 

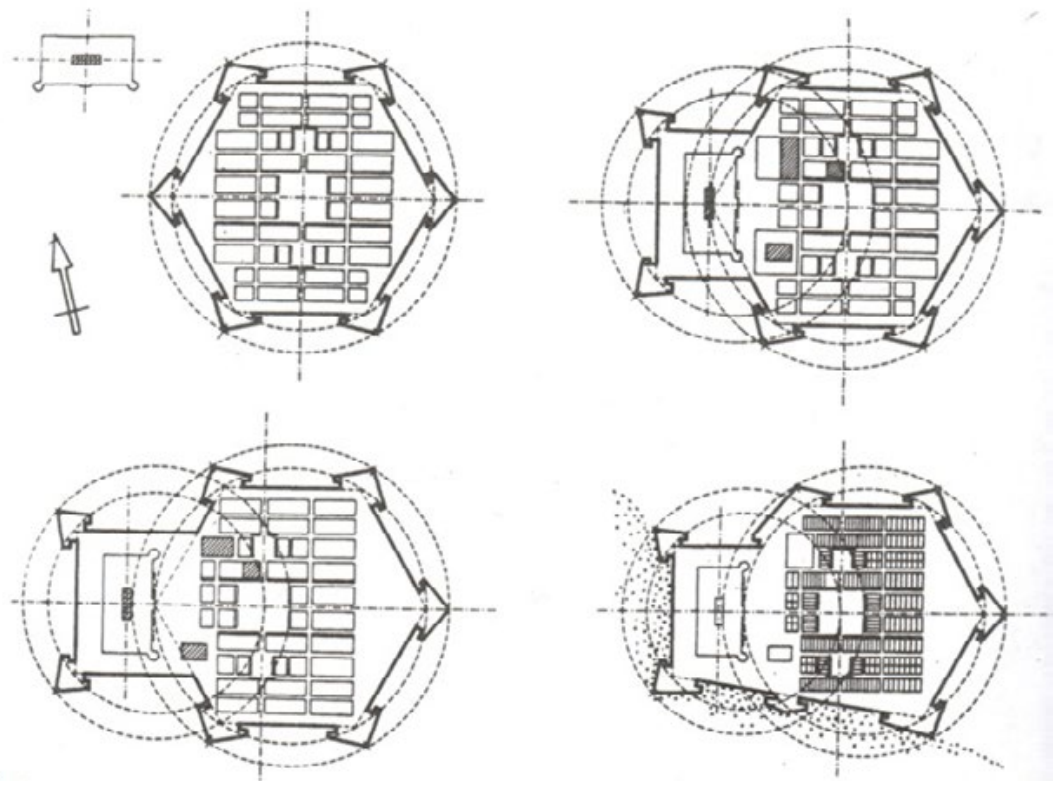

Ryc. 1. Próba odtworzenia głównych faz zespalania miasta $z$ rezydencją oraz form kształtowania planu według Teresy Zarębskiej.

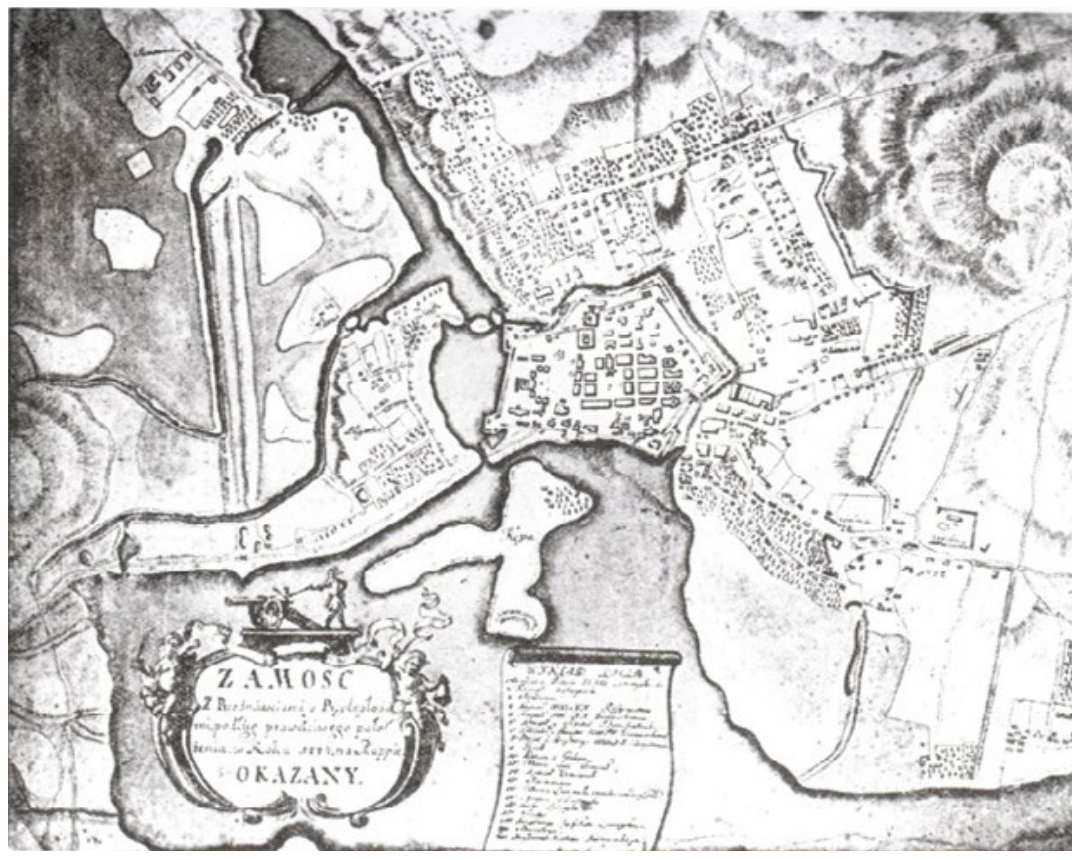

Ryc. 2. Zamość - plan sytuacyjny (1774), widoczny układ wodny, który wywarł wpływ na odkształcenie regularnego modelu miasta, według W. Ostrowskiego.

Po przyjęciu uchwały z 1974 roku stało się niezbędne przygotowanie odpowiedniej dokumentacji. Udało mi się przekonać decydentów, aby powierzyć jej wykonanie zespołowi autorskiemu rzeszowskiej Pracowni Konserwacji Zabytków kierowanemu przez Andrzeja Piątka i Janusza Macha. Wybór ten wynikał z bardzo wysokiej oceny wcześniej wykonanego przez nich studium Jarosławia ${ }^{6}$.

Współpracował z nimi zespół naukowo-historyczny Pracowni Konserwacji Zabytków w Lublinie pod kierunkiem K. Majewskiego. Postanowiono, że plan będzie miał charakter planu szczegółowego, opartego na obowiązującej ustawie o planowaniu przestrzennym. Wykonano szczegółową inwentaryzację urbanistyczno-architektoniczną Zamościa oraz studium historyczno-urbanistyczne. 
Inwentaryzacja została opracowana w skali 1:500 (urbanistycznej) i w skali 1:250 (architektonicznej). Uzupełniono ją o pełną inwentaryzację formy miasta (4 panoramy w skali 1:500, 28 rozwinięć ciągów pierzei w skali 1:250) i krajobrazu miejskiego (35 rysunków z natury oraz zestaw zdjęć fotograficznych) ${ }^{7}$.

Drugim podstawowym opracowaniem było studium historyczno-urbanistyczne miasta Zamościa, wykonane przez zespół Pracowni Konserwacji Zabytków w Lublinie oraz głównych projektantów planu. Jednym z ważnych zadań tego opracowania było podsumowanie aktualnego stanu wiedzy o Zamościu. W studium wykorzystano zebrane materiały kartograficzne i ikonograficzne. Stanowiły one ponadto przedmiot odrębnej analizy wykonanej przez zespół autorski planu (A. Piątek, J. Mach i T. Piątek).

Opracowanie to pod nazwą "Studium stanu zachowania układu urbanistycznego ..." określiło autentyczność zachowanych elementów poziomego i pionowego układu miasta i jego fortyfikacji. W efekcie powstała rysunkowa rekonstrukcja formy zewnętrznej Zamościa.

Zespoły autorskie dokonały analizy problematyki konserwatorskiej w opracowaniu pt. „Ustalenia i wnioski konserwatorskie do planu rewaloryzacji zespołu zabytkowego w Zamościu". Opracowanie to zawierało syntetyczne podsumowanie stanu wiedzy historyczno-urbanistycznej i stanu zachowania układu przestrzennego Zamościa, wyznaczenie stref ochrony konserwatorskiej wraz z określeniem kryteriów działania w tych strefach, omówienie charakteru dopuszczalnych działań w obiektach zabytkowych i na obszarze chronionym oraz liczne szczegółowe postulaty i zalecenia do planu. Wnioski te zostały później uściślone w planie szczegółowym, uzyskując tym samym rangę wytycznych konserwatorskich.

Podstawowe założenia planu szczegółowego ostatecznie określiły granice I strefy bezpośredniej ochrony konserwatorskiej układu zabytkowego. Obszar znajdujący się w tych granicach miały stanowić przedmiot czynnej rewaloryzacji konserwatorskiej. Pozostały obszar objęty planem szczegółowym niemal w całości pokrywał się z zasięgiem Il strefy ochrony pośredniej układu i jego otoczenia.

Niewątpliwie najbardziej kontrowersyjne z dzisiejszego punktu widzenia było odgórne ustalenie funkcji poszczególnych budynków. Było to charakterystyczne dla realiów czasu, gdy praktycznie nie istniało pojęcie prywatnej własności. Nie mniej autorzy planu podkreślali, że ustalenia funkcjonalne były ramowe i traktowane elastycznie. Warto podkreślić, że na obszarze zespołu morandowskiego nie dopuszczono lokalizacji wielkogabarytowych budynków służących usługom masowym (domy towarowe, duża gastronomia, duże hotele) z uwagi na ich wymagania technologiczne i komunikacyjne, a także ze względów kompozycyjnych (Ryc. 3).

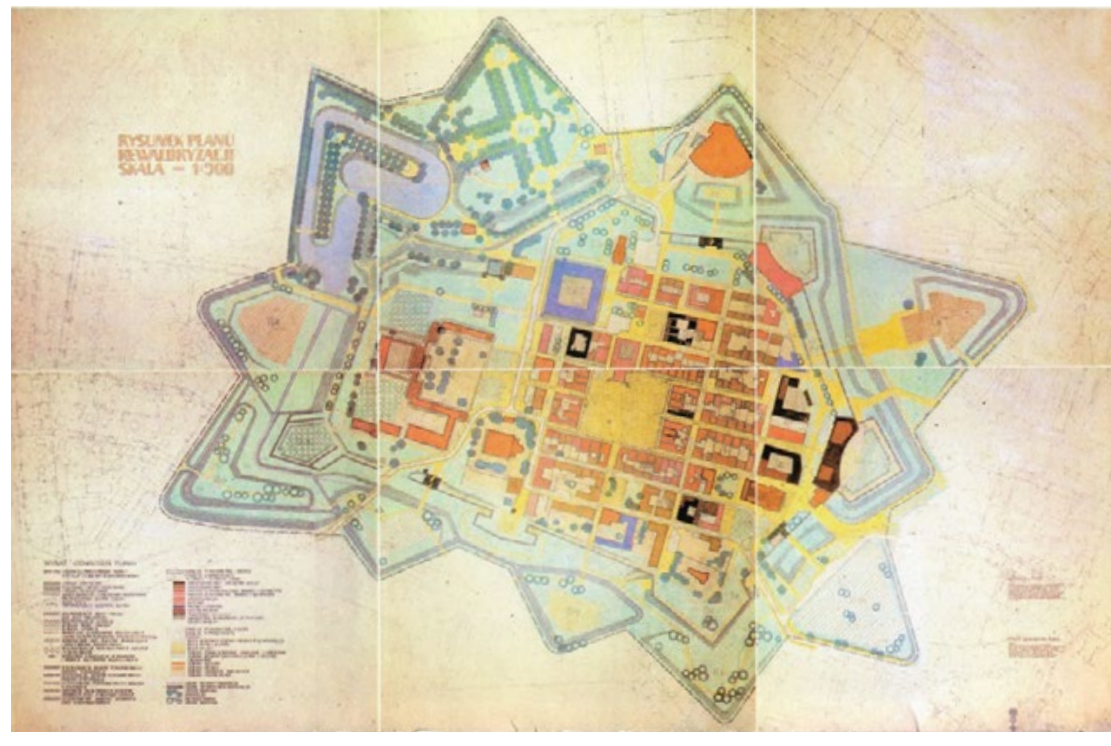

Ryc. 3. Zamość - plan rewaloryzacji, opracował A. Piątek i J. Mach z zespołem.

Obszar leżący na zewnątrz strefy l, a objęty miejscowym planem szczegółowym miał stworzyć przestrzenny dystans między zespołem zabytkowym a nową zabudową rozwijającego się miasta. Rozwiązanie to respektowało 
zachowane do dziś dawne przedpole twierdzy zamojskiej. Ustalenia planu szczegółowego nakazywały utrzymanie pozostałości tego przedpola. Miało być ono zakomponowane niską zielenią i pełnić funkcję terenów spacerowo-zabawowych, z systemem połączeń pieszych o charakterze ogólno miejskim i lokalnym. Sformułowano zakaz wznoszenia wszelkiej zabudowy, a także wprowadzania w sposób dowolny wysokiej zieleni. Stąd się bowiem roztacza najlepszy widok na zespół zabytkowy Zamościa.

Szczególnie istotne były opracowania "Studium krajobrazu zespołu staromiejskiego" oraz "Studium kompozycji wnętrza miasta historycznego" autorstwa S. Wierciocha ${ }^{8}$ (Ryc. 4). Przyniosły one przewartościowanie poglądów na temat zespołu zabytkowego jako nadrzędnego elementu kompozycji krajobrazowej.

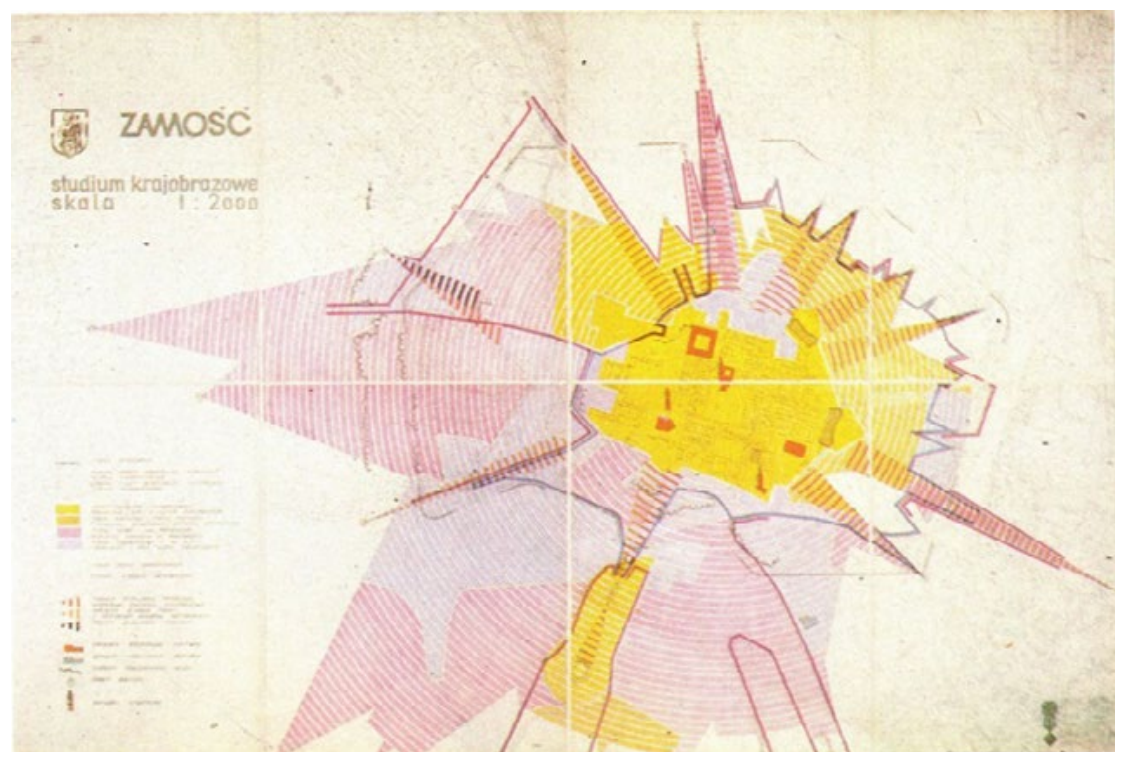

Ryc. 4. Zamość - studium krajobrazowe, oprac. S. Wiercioch.
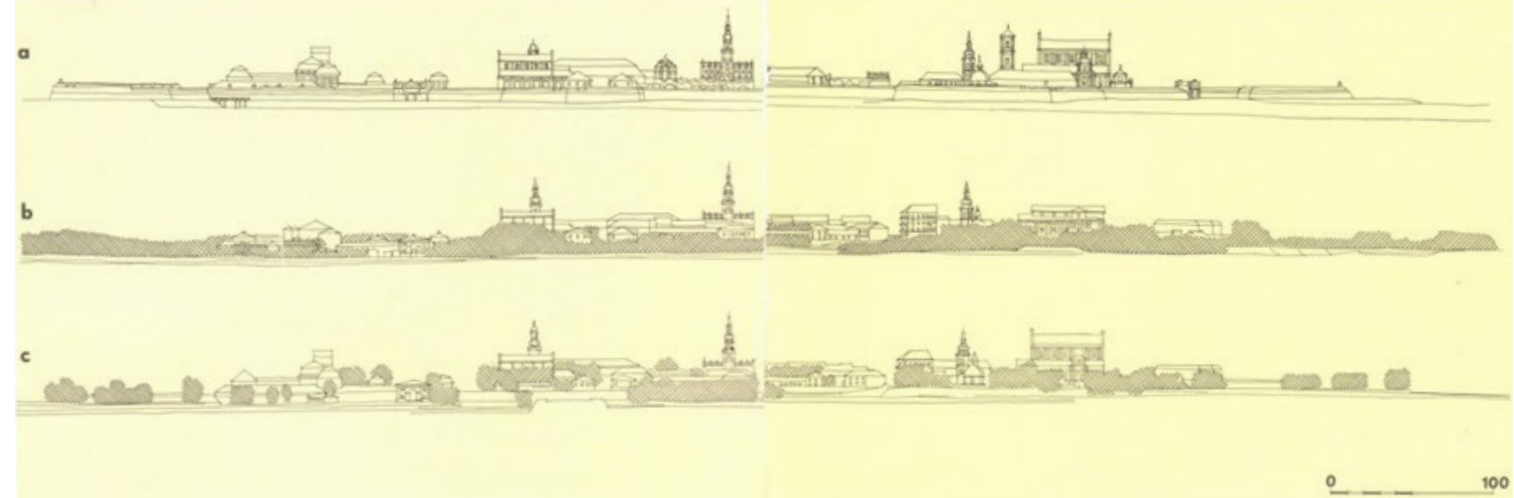

Ryc. 5. Studium panoramy miasta od strony południowej: a) stan z II połowy XVIII w.; b) stan istniejący; c) projektowany stan po rewaloryzacji. Oprac. J. Mach i T. Piątek.

W 1974 roku podjęte zostały również studia nad ukształtowaniem nowego centrum i jego związków z zespołem staromiejskim. W rezultacie konkursu problem ten powierzono zespołowi "Warcentu" kierowanemu przez architekta Jacka Jedynaka (Ryc. 7). Przedstawiony przez niego projekt stanowił próbę stworzenia niejako paralelnego do zabytkowego układu organizmu zbudowanego z elementów współczesnej architektury9. 
Ta dyskusyjna propozycja wynikała z chęci wprowadzenia ładu przestrzennego opartego w swej zasadniczej koncepcji na replice koncepcji Moranda. Podejście zmuszające do podporządkowania się narzuconym rygorom było możliwe do realizacji przy założeniu zaangażowania potężnego, wówczas tylko państwowego, inwestora. Tak się nie stało i wzniesiono zaledwie jeden obiekt administracyjny (Ryc. 8).

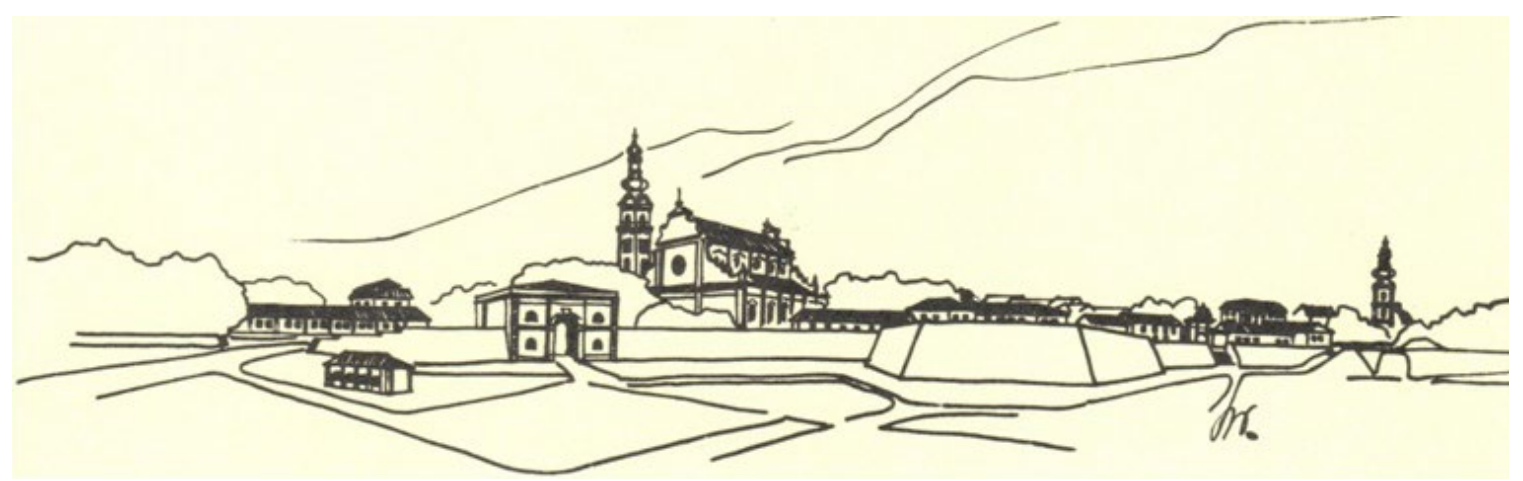

Ryc. 6. Widok zespołu staromiejskiego od strony południowo-zachodniej - projekt oprac. A. Piątek i S. Wiercioch.

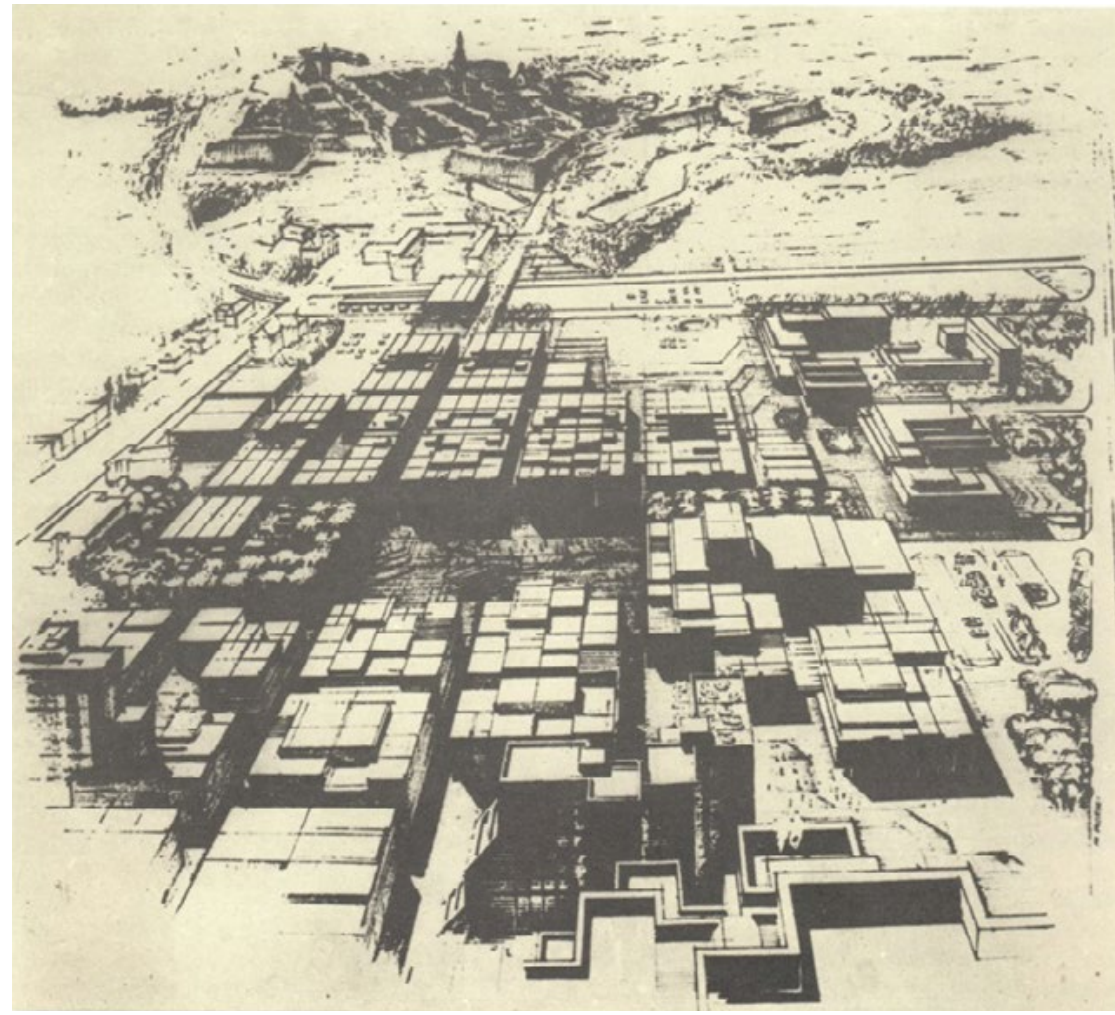

Ryc. 7. Nowe centrum - jego powiązanie ze starym miastem według projektu oprac. przez zespół "Warcentu" pod kierunkiem architekta Jacka Jedynaka.

W okresie późniejszym tendencje do aranżacji nowej zabudowy w nawiązaniu do modularnego układu brył i fasad zespołu morandowskiego znalazła wyraz w koncepcjach osiedla imienia Jana Zamoyskiego ${ }^{10}$.

Projekty dotyczące trójwymiarowej kompozycji miasta renesansowego przedstawiono w skalach 1:500 i 1:250 (rozwinięcie pierzei ulic, projekty panoram Zamościa, szkice perspektywiczne). Zaplanowana rekompozycja systemów fortyfikacji przez przywrócenie im historycznego gabarytu miała stanowić pierwsze ważne przedsięwzięcie: ujęcia kompozycji miasta jako całości (Ryc. 5, 6). 


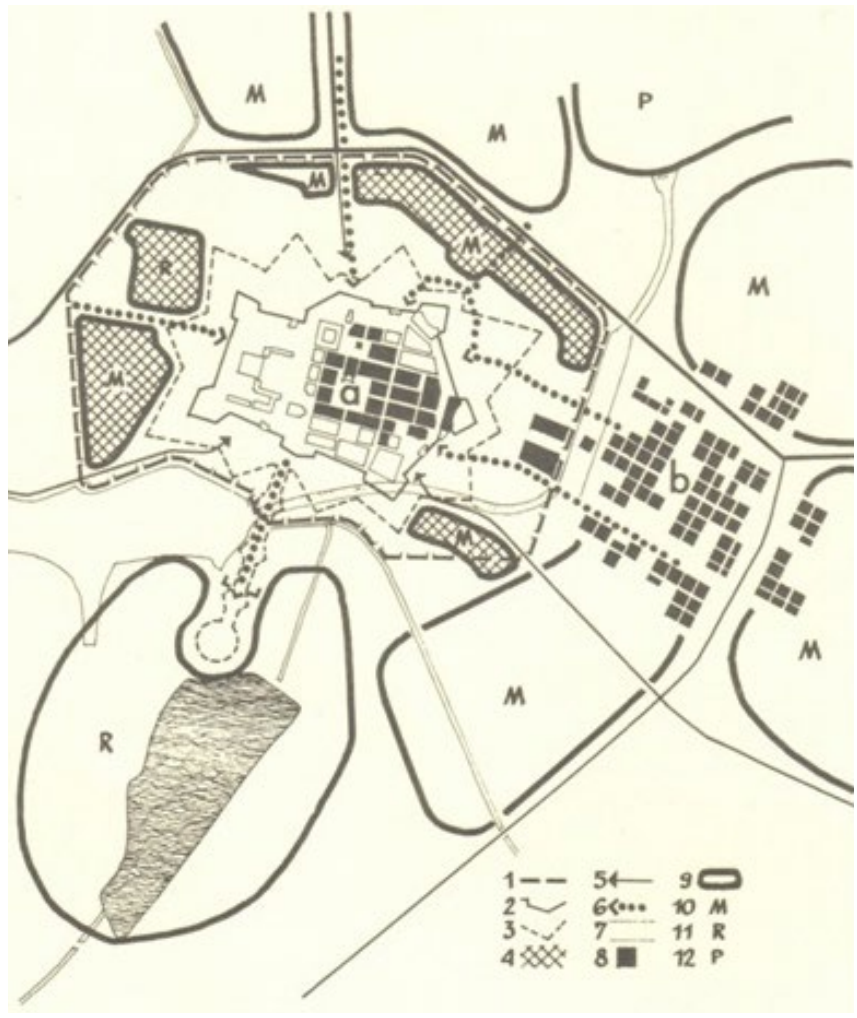

Ryc. 8. Położenie zespołu zabytkowego w strukturze miasta, oprac. T. Piątek.

1 - granica opracowania szczegółowego planu zagospodarowania przestrzennego i rewaloryzacji, 2 - narys fortyfikacji renesansowo-barokowych, 3 - twierdza XIX-wieczna 4 - elementy kolidujące $z$ teoretycznym zasięgiem ochrony otoczenia układu zabytkowego, 5 - system obsługi ruchem kołowym, 6 - główne powiązania piesze, 7 - cieki wodne, 8 - koncentracja elementów centralnego ośrodka usługowego (a - ośrodek historyczny - 1 ognisko centralnego ośrodka usługowego, b - nowe centrum - II ognisko centralnego ośrodka usługowego), 9 - granice obszarów $\mathrm{M}, \mathrm{R}, \mathrm{P}, 10$ - zespoły mieszkaniowe w zasadzie powojenne, 11 - obszary rekreacji i sportu, 12 - dzielnica przemysłowo-magazynowa.

Autorzy podkreślali, że istnieją pewne, niewątpliwie dyskusyjne, ale bardzo kuszące możliwości rekompozycji wartości, których rola w zarówno w wewnętrznych widokach, jak i w panoramie Zamościa byłaby ogromna, ale niektóre z nich wymagały naukowego rozważenia.

Wszystko, co określano pojęciem rekonstrukcji lub odtworzenia, nie zostało zakwalifikowane jako decyzja planu. Ustalono, że decyzje podjęte zostaną indywidualnie po wyczerpującym przygotowaniu naukowo-badawczym i dokumentacyjnym. Uznano, że istotna jest „kompleksowa analiza dopuszczalności działań, nie zawsze zgodnych z teorią konserwatorstwa, które jednak w praktyce niejednokrotnie są potrzebne i okazują się najbardziej trafne"11.

Opracowanie Andrzeja Piątka i Janusza Macha znalazło się w licznych publikacjach, również w wersjach angielskiej i francuskiej i długo było uznawane za wzorcowe. Na jego też podstawie podjęto nowy etap rewaloryzacji rozpoczynając od Rynku Wielkiego.

Ważnym elementem dopingującym do wzmożonego tempa prac stało się w 1980 r. 400-lecie założenia miasta przez hetmana i kanclerza koronnego Jana Zamoyskiego.

Data ta zbiegła się z zorganizowaną w Krakowie przez Polski Komitet Narodowy ICOMOS międzynarodową konferencją na temat sposobu wdrażania w życie „Rekomendacji Warszawskiej" UNESCO dotyczącej ochrony zespołów zabytkowych i tradycyjnych i ich roli w życiu współczesnym ${ }^{12}$. Z inicjatywy ówczesnego konserwatora miasta Zamościa pani Maryli Sarnik i prezesa PKN ICOMOS uczestnicy obrad tej konferencji, specjaliści z kilkudziesięciu krajów mogli się zapoznać z prowadzonymi w nim pracami rewaloryzacyjnymi. Spotkanie to pomyślane było również jako pierwsze działanie zmierzające do umieszczenia Zamościa na Liście Dziedzictwa Światowego.

Splot różnorodnych okoliczności sprawił, że kandydatura ta mogła zostać oficjalnie zgłoszona w imieniu rządu Polskiego przez dyrektora Ośrodka Dokumentacji Zabytków Marka Konopkę dopiero w 1991 roku. Stała się ona przedmiotem ożywionej debaty na forum sesji Komitetu Dziedzictwa Światowego w Tunisie, gdzie dzięki uzupełniającej dokumentacji zaprezentowanej przez Michała Witwickiego została dopuszczona do dalszej procedury. 
W lipcu 1992 roku Zamość był prezentowany na wystawie w gmachu UNESCO w Paryżu, ale ostatecznie dopiero w grudniu 1992 r. na sesji Komitetu w Santa Fe (USA) został wpisany na Listę Światową (Ryc. 9). Dziękując Komitetowi za zaliczenie Zamościa do miast o uniwersalnej wartości złożyłem wtedy zobowiązania, że przestrzegać będziemy postulatów, które zostały sformułowane pod adresem miasta.
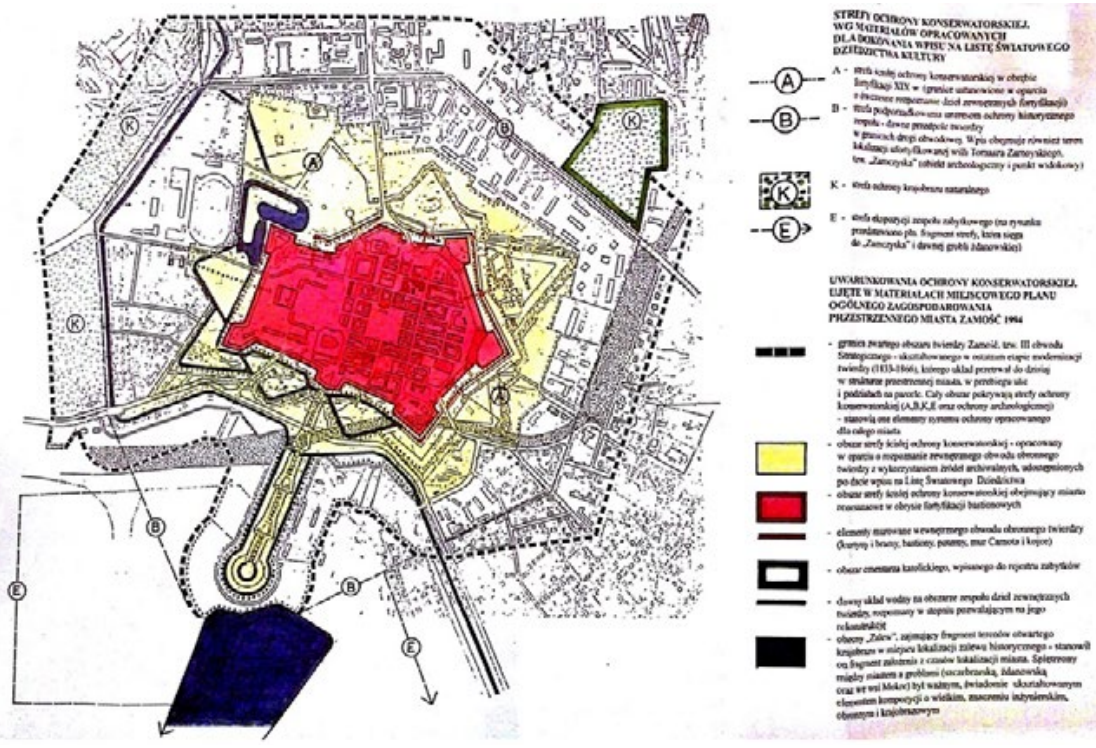

Ryc. 9. Zamość - planistyczne uwarunkowania ochrony konserwatorskiej - podstawowa plansza w dossier dotyczącym wpisu na Listę Światowego Dziedzictwa UNESCO.

W 5 lat po dokonaniu wpisu uznaliśmy, że należy zgodnie z ogólnymi zaleceniami Komitetu Dziedzictwa Światowego przeprowadzić monitoring zespołu staromiejskiego. Został on opracowany na podstawie kwestionariusza przygotowanego przez niżej podpisanego zgodnie z wytycznymi UNESCO ${ }^{13}$. Za szczególnie ważne uznaliśmy uzyskanie informacji jak przebiega proces rewaloryzacji w radykalnie zmienionych warunkach politycznych, po odejściu od zasad odgórnie sterowanej gospodarki rynkowej. Zdaliśmy sobie sprawę z konieczności adaptacji dawnych programów zapisanych w planach zagospodarowania przestrzennego do nowych realiów. Potwierdziły to analizy wskazujące na konieczność nowej strategii działania. Elaborat nasz wskazywał na kierunki realnych i potencjalnych zagrożeń dla substancji zabytkowej miasta.

Monitoring uzupełniony został w 1998 roku o opracowanie socjologiczne, gdyż uznaliśmy, że opinie społeczności lokalnej są elementem o pierwszorzędnym znaczeniu dla właściwego procesu rewaloryzacji miasta. Zauważmy, że ankieta opracowana przez dr Waldemara Siemińskiego wykazała, że problem ochrony i konserwacji zabytków uznany jest przez mieszkańców Zamościa jako jedna z najważniejszych potrzeb miasta. Ważne jest, że niemal $100 \%$ obywateli uznawało za wysoce pożądaną wzmożoną frekwencję turystyczną, zauważając przy tym niedostatki w infrastrukturze miasta w tym zakresie.

Podkreślić należy, że wyniki monitoringu służyć miały nie tylko Zamościowi. Inicjatywa ta stanowiła ważne ogniwo realizacji programu „Ochrona i zarządzanie miast o szczególnej wartości zabytkowej” opracowanego przez Polski Komitet Narodowy ICOMOS i aprobowanego przez UNESCO, Komitet Miast Historycznych oraz Sekretariat ICOMOS. W ten sposób umacniała się międzynarodowa pozycja Zamościa, który w 1994 roku zorganizował seminarium na temat ochrony i zarządzania w miastach wpisanych i kandydujących na Listę Światową UNESCO $^{14}$. Następnie w 1997 roku przygotowaliśmy pierwsze sympozjum na ten temat, współorganizowane przez Lwów i Kamieniec Podolski oraz Komitety Narodowe ICOMOS Polski i Ukrainy. Zostało ona zakończone rezolucją proponującą utworzenie Stałej Konferencji Miast Zabytkowych Europy Środkowo-wschodniej.

13 Zamość - monitoring miejskiego zespołu zabytkowego dziedzictwa światowego UNESCO, PKN ICOMOS, Warszawa 1998. Opracowanie: mgr inż. arch. Maryla Sarnik-Konieczna, mgr inż. arch. Andrzej Cygnarowski, mgr inż. arch. Barbara Skórzyńska-Terlecka, dr Waldemar Siemiński, mgr inż. arch. Michał Witwicki, mgr Urszula Fidecka, konsultacja naukowa prof. dr hab. inż. arch. Krzysztof K. Pawłowski.

14 Ochrona i zarządzanie miastami wpisanymi i typowanymi na Listę Światowego Dziedzictwa Kultury UNESCO w Europie Środkowo-wschodniej Zamość, Lwów, Kamieniec Podolski, PKN ICOMOS 1997. 
W wyniku narad w Zamościu, Pecsu i Elblągu w 1998 r. postanowiono, że Sekretariat Stałej Konferencji będzie umiejscowiony w Zamościu.

Monitoring rozpoczyna się ustaleniami o charakterze ogólnym, charakteryzującym podstawowe zasady ochrony, wynikające z zastosowania Konwencji UNESCO ${ }^{15}$.

Stwierdzono w nim, że w obowiązującym planie ogólnym zagospodarowania przestrzennego Zamościa (Ryc. 9) obszar przedstawiony na rysunku wpisu na Listę Światowego Dziedzictwa w całości pokryty jest różnymi strefami ochrony konserwatorskiej, a mianowicie: A, B, K, E, spełniającymi różne cele ochrony. Strefy ochrony konserwatorskiej zostały opracowane na potrzeby ochrony zamojskiego zespołu zabytkowego, tworząc system zabezpieczeń w skali całego miasta i obejmują: elementy przedlokacyjne, wyodrębnioną jednostkę, jaką jest "miasto renesansowe", drogi, groble, system wodny z zalewem, obszary otwarte po płd. stronie, jako zamierzone pole ekspozycji, elementy późniejszych przekształceń twierdzy i sieci osadniczej, drożnej, wodnej oraz rezydencje i kościoły.

Strefę "buforową" zamojskiego zespołu zabytkowego tworzy system stref funkcjonujących w ramach jednostek urbanistycznych planu ogólnego Zamościa w formie określonych granic obszarów i powiązań funkcjonalno-przestrzennych, a także krajobrazowych. Utworzenie takiej otuliny w formie strefy stanowiło priorytet w opracowaniu założeń do planu, a następnie zostało wykorzystane przy opracowaniu planu ogólnego zagospodarowania przestrzennego Zamościa.

Te uwagi doprowadziły do sformułowania wniosków natury ogólnej, stwierdzających że ważnym warunkiem, mającym niemalże podstawowe znaczenie w ochronie zespołów staromiejskich, zwłaszcza dla zamojskiego zespołu zabytkowego, wpisanego na Listę Światowego Dziedzictwa jest ochrona jego otuliny. Tymczasem w obowiązujących przepisach, w tym również w ustawie o ochronie dóbr kultury, pojęcie to nie miało umocowania prawnego. Ustawa mówi o rejestrze zabytków, w którym pojęcie "otoczenia" też nie jest uwzględnione, a zatem ochrona otoczenia zespołu zabytkowego w planach zagospodarowania przestrzennego funkcjonuje jedynie poprzez zapisy w strefach ochrony konserwatorskiej, których ustanowienie wynika z przepisów ogólnych.

Zwrócono uwagę, że w studium historyczno-urbanistycznym należy na nowo określić wszystkie obiekty oraz granice, które tworzą przedmiot chroniony w celu jednoznacznego stwierdzenia, czy przedmiotem ochrony jest teren miasta renesansowego, miasto z twierdzą z XIX wieku, lub jeszcze szerzej, a więc miasto wraz z południowym obszarem „pozalewowym” jako elementem zabytkowego zespołu miasta lokacyjnego.

Z przeprowadzonego rozpoznania wynika, że strefy ochronne wymagają modyfikacji. Czynność tę należy poprzedzić wykonaniem studium historyczno-urbanistycznego.

Konieczne jest skoordynowanie wskazań i zapisów konserwatorskich oraz poszerzenie strefy ochrony konserwatorskiej, ponieważ pozyskana wiedza i dostępne materiały archiwalne, po wykonaniu prac studialnych, pozwalają na nowe zdefiniowanie i korektę zasad ochrony konserwatorskiej na tym terenie.

Zalecenia Komitetu Dziedzictwa Światowego, choć są zawarte w planie zagospodarowania przestrzennego Zamościa, w zasadzie nie zostały dotychczas wdrożone i w najbliższej przyszłości nie ma realnych szans na ich realizację z przyczyn obiektywnych takich jak zalecenie dotyczące likwidacji istniejącej zabudowy mieszkalnej osiedla "Planty".

W monitoringu podkreślano, że wpis Zamościa na Listę Światowego Dziedzictwa jest ważnym elementem stymulującym wdrażanie szerokiego programu ochrony i rewaloryzacji zespołu zabytkowego i jego otoczenia. Realizowany miałby być zgodnie z zapisami planu ogólnego zagospodarowania przestrzennego w obrębie wyznaczonych stref ochrony konserwatorskiej. Podejmowane działania mają na celu zachowanie, a także przywracanie jego uniwersalnych wartości poprzez ogólne określenie charakteru działań w poszczególnych strefach, a mianowicie:

Zmiany przeznaczenia niewłaściwie użytkowanych terenów dla odtworzenia m.in. fragmentów fortyfikacji,

- Usunięcia obiektów dysharmonizujących i niszczących przestrzeń zabytkową, jak np.: kolej,

- Niezbędne rekonstrukcje dla uczytelnienia zabytkowej struktury przestrzennej jak np.: odtworzenie fragmentów fortyfikacji,

- Uzupełnienie starej zabudowy,

- Rewaloryzację krajobrazu kulturowego w szczególności renesansowych i XIX-wiecznych fortyfikacji. 


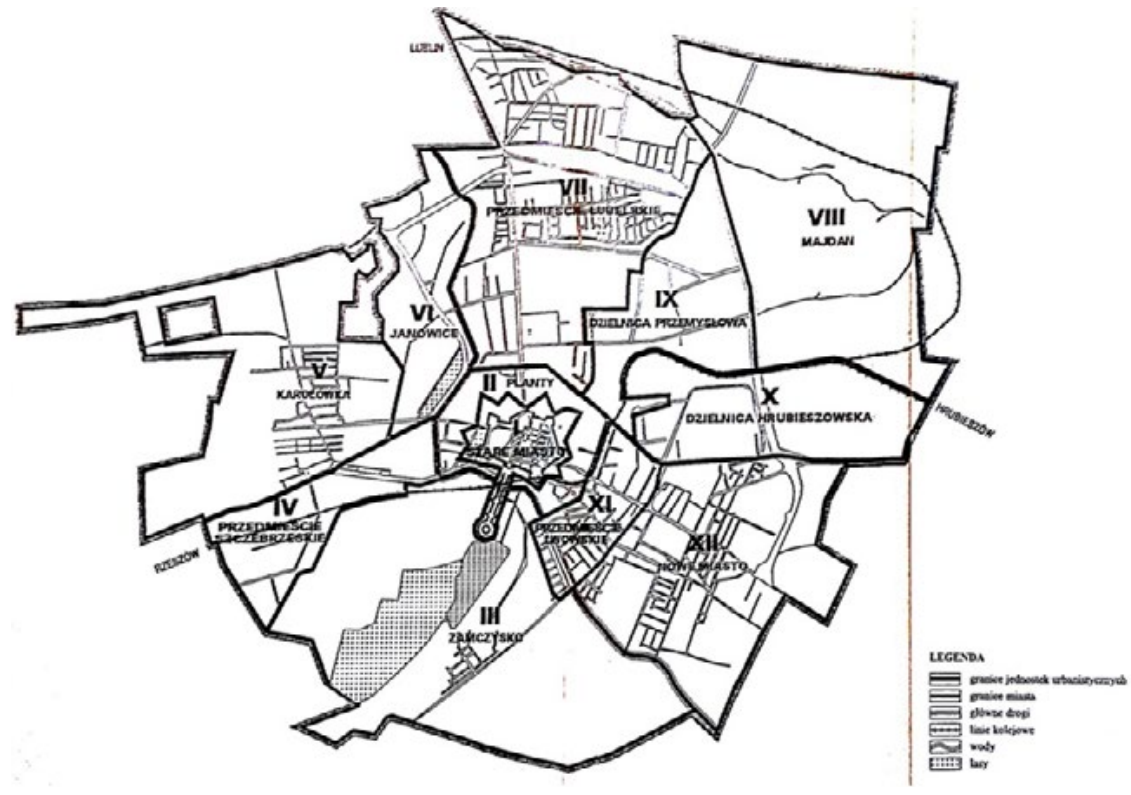

Ryc. 10. Podział miasta na jednostki urbanistyczne.

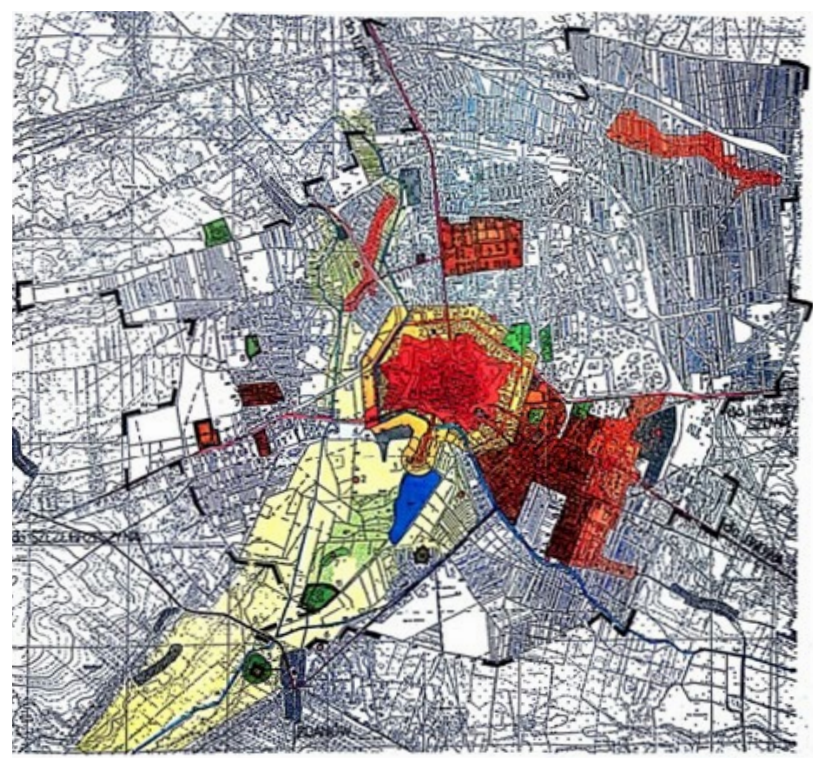

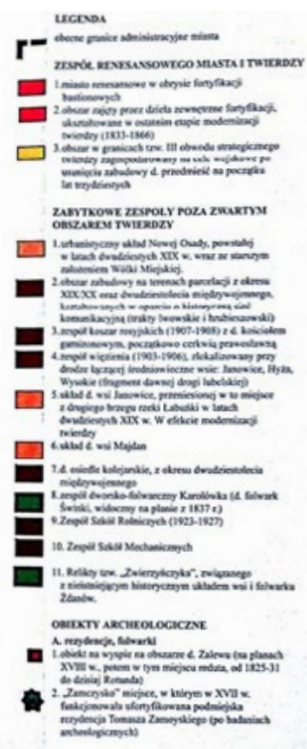

Ryc. 11. Zabytkowe zespoły i elementy historycznej struktury funkcjonalno-przestrzennej Zamościa w obecnych granicach miasta.

Na zadane w monitoringu pytanie: czy nadal zespół wyróżnia się pozytywnie w skali regionu (w pojęciu międzynarodowym) spośród innych o podobnym charakterze - odpowiedź była pozytywna. Zmiany w gospodarce i w sposobie funkcjonowania inicjatyw społecznych, a nade wszystko szeroka współpraca trans graniczna i euroregionalna oraz międzynarodowe kontakty Zamościa i postępujące prace rewaloryzacyjne stanowią gwarancję zachowania zamojskiego zespołu zabytkowego jako cennego obiektu światowego dziedzictwa kulturalnego.

Kolejne pytanie brzmiało: czy nowe inwestycje lub nowe funkcje na obszarze bezpośrednio sąsiadującym z zamojskim zespołem zabytkowym nie zagrażają jego integralności?

Z konserwatorskiego punktu widzenia zagrożenie nowymi inwestycjami już zaistniało, dotyczy to zwłaszcza pierścienia terenów pofortecznych, które dotychczas pozostawały bez zabudowy. Teren ten w planie objęty jest strefą "A" $\mathrm{i}$ „B" ochrony konserwatorskiej, ale pojawiły się elementy degradacji zespołu przez wprowadzenie niewłaściwych dotychczas miejskich funkcji, oraz trwałe rozdysponowanie części terenów objętych ochroną, a więc sprzedaż dokonywaną wraz z obiektami, a także wieloletnie wydzierżawienie terenów i obiektów. Zagraża to realizacji podstawowego postulatu konserwatorskiego, jakim jest sukcesywna likwidacja obiektów 
oraz uciążliwych funkcji, zakłócających integralność zespołu chronionego, w celu porządkowania i „otwierania” widoków miejskich.

Miejski Konserwator Zabytków Maryla Sarnik-Konieczna uważała, że plan ten w pełni respektował ustalenia planu rewaloryzacji. Mankamentem tego opracowania był brak ustaleń dotyczących kompleksowej ochrony krajobrazu kulturowego poza obszarem zespołu zabytkowego, co wynikało z braku badań w tym zakresie.

Dlatego w monitoringu przedstawiono plansze z podziałem miasta na jednostki urbanistyczne (Ryc. 10) oraz z oznaczonymi ważnymi jednostkami osadniczymi wskazującymi na potrzebę ich zespolenia (Ryc. 11).

Kolejny etap wzmożonych działań inwestycyjnych na terenie Zamościa nastąpił po akcesji Polski do Unii Europejskiej, co dało między innymi pozyskanie nowych źródeł finansowania.

Zamość stał się obszarem intensywnych działań inwestycyjnych i, co szczególnie istotne, prac konserwatorskich.

Objęły one w znacznym stopniu obszary forteczne według projektu prof. Zbigniewa Myczkowskiego (Ryc. 12). Były one analizowane w wielu raportach i publikacjach ${ }^{16}$.

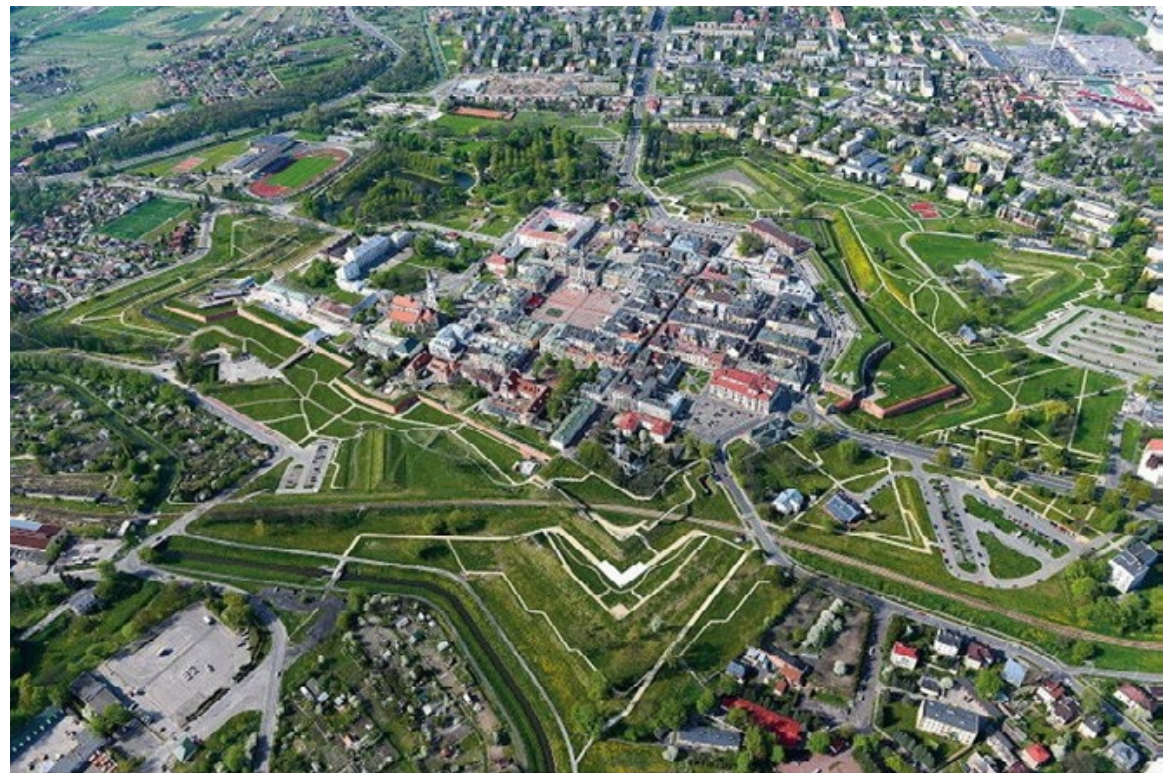

Ryc. 12. Zamość - widok lotniczy zespołu w obrębie obwarowań po zabiegach rewitalizacyjnych.

Natomiast problem integracji nowych dzielnic stał się tematem warsztatów studenckich Wydziału Budownictwa i Architektury Politechniki Lubelskiej pod kierunkiem prof. Jana Wrany ${ }^{17}$.

Spełnienie warunków wynikających z tych studiów będzie mogło przyczynić się do ograniczenia chaosu przestrzennego wokół wspaniale wyeksponowanego zespołu zabytkowego.

Tym samym będą mogły stanowić ważny krok w kierunku realizacji sformułowanego w 2011 roku zalecenia UNESCO w sprawie historycznego krajobrazu miejskiego.

16 Z. Myczkowski - Krajobraz warowny twierdzy Zamość w kontekście idei tożsamości miejsca i jej składników, Teka Komisji Urbanistyki i Architektury PAN Kraków, tom XLIII. Prof. Zbigniew Myczkowski, architekci Jerzy i Ewa Wowczak - Analiza sposobu zagospodarowania strefy południowego przedpola zespołu miasta wraz z XIX wiecznymi umocnieniami (www.wowczak.pl), Zbigniew Myczkowski - Kontekst krajobrazowy a ochrona miejsc niezwykłych, w tym na przykładzie Zamościa (Konferencja z okazji 25-lecia wpisu na Listę Światową wrzesień 2017).

17 J. Wrana - Synergia w nieidealnym mieście „idealnym” - próby zintegrowania Zamościa. Budownictwo i Architektura vol. 16(1), Politechnika Lubelska 2017, s. 5 i nn 